\title{
8 Infectieziekten
}

Prof. dr. A.I.M. Hoepelman, drs. J.C. Dutilh, drs. L.J. Maarschalk-Ellerbroek, drs. S.F.L. van Lelyveld, dr. A. Troelstra en prof. dr. Th.J.M. Verheij

\section{INLEIDING}

In dit hoofdstuk wordt beoogd de belangrijkste nieuwe ontwikkelingen waarvan de huisarts moet kennisnemen, te bespreken. Voor specifieke therapie wordt verwezen naar hoofdstuk 25 Antimicrobiële therapie waaraan wij ook hebben bijgedragen.

\section{ZIEKTEBEELDEN}

\subsection{Infecties bij gestoorde afweer}

De gastheerweerstand tegen infecties kan door veel ziekteprocessen maar ook therapeutische interventies ernstig verstoord raken.

De eerste verdedigingslinie wordt gevormd door intacte huid en slijmvliezen. Deze verdedigingslinie kan door aantasting van de integriteit (bijv. een infuus, wonden of katheterisaties), aantasting van de kwaliteit, zoals secretie (talg, zweet, mucus of minder maagzuur door bijv. protonpompremmers!) of aantasting van de beweging (trilhaarfunctie, blaasontledigingsstoornis) bijdragen aan het ontstaan van infecties.

Stoornissen in de gastheerweerstand kunnen aangeboren (primair) zijn of verworven (secundair).

De gastheerweerstand kan primair worden ingedeeld in humoraal en cellulair en secundair in specifiek en niet-specifiek. De belangrijkste componenten van de humorale afweer bestaan uit het complementsysteem (niet-specifiek) en immunoglobulinen (specifiek). De cellulaire afweer wordt ook verdeeld in niet-specifiek (fagocyterende cellen, NKcellen) en specifiek (T-lymfocyten en macrofagen).

De volgende omstandigheden kunnen een indicatie zijn voor een immuundeficiëntie.
Infectieuze aanwijzingen voor immuundeficiëntie:

- recidiverend karakter;

- ongewoon of onverwacht ernstig beloop;

- onverwacht langdurig herstel;

- onverwachte complicaties;

- bijzondere of opportunistische verwekkers.

Niet-infectieuze aanwijzingen voor immuundeficiëntie:

-slechte wondgenezing;

- onverklaarde bronchiëctasieën;

- chronische diarree of tekenen van malabsorptie;

- 'failure to thrive' bij jonge kinderen.

\section{Diagnostiek}

Naast een zorgvuldige anamnese, familieanamnese en lichamelijk onderzoek, worden als eerste stap in het bloedonderzoek de volgende bepalingen geadviseerd:

$-\mathrm{Hb}$, leukocytenaantal met differentiatie en trombocytengetal;

- nier- en leverfunctie;

-albumine, glucose;

- urinesediment op eiwit;

-(indien mogelijk) immuunglobulinen IgA, IgM en IgG met eventueel subklassen van IgG;

-(indien mogelijk) complement screening;

-hiv-test

- eventueel CD4.

\subsection{Stoornissen van de humorale afweer}

\section{Niet-specifiek: het complementsysteem}

Een deficiëntie van het complementsysteem kan verworven zijn en aangeboren. De frequentie van een aangeboren deficiëntie is laag (o,03\%). Verwor- 
ven oorzaken van een deficiëntie van het complementsysteem kunnen ondervoeding en diabetes mellitus zijn.

Bij bepaalde deficiënties van onderdelen van het complementsysteem (bijv. $\mathrm{C}_{3}$ ) zijn recidiverende infecties door gekapselde bacteriën (bijv. pneumokokken) een belangrijk aspect. Deficiënties van de late factoren van het complementsysteem (C6-C8) kunnen aanleiding geven tot chronische en recidiverende infecties ten gevolge van meningokokken en gonokokken.

\section{Therapie}

Behandeling bestaat voor sommige deficiënties uit het toedienen van het tekort aan complement, of antibioticaprofylaxe en vaccinatie tegen voornoemde verwekkers.

\section{Specifiek: immuunglobulinen}

Voorbeelden van aangeboren hypo- of agammaglobulinemie (tekort aan immunoglobulinen) zijn $\mathrm{X}$-gebonden agammaglobulinemie (XLA) en common variable immunodeficiency syndroom (CVID's).

CVIDs is de meest voorkomende humorale immuundeficiëntie en heeft een geschatte incidentie van 1/10.000-50.00o in de gehele populatie. Criteria voor het stellen van de diagnose CVIDs zijn een verlaagde IgG, IgA en mogelijk IgM, ziektebeeld ontstaan na de leeftijd van 2 jaar en een gestoorde vaccinatierespons op o.a. een polysacharidenvaccin. De geschatte overleving 20 jaar na diagnose is $65 \%$. De meeste primaire humorale immuundeficiënties (bijv. XLA) komen in het eerste levensjaar tot uiting, maar CVIDs kan ook pas tussen het zoe en 40 e levensjaar tot expressie komen met recidiverende bovenste en onderste luchtweginfecties als belangrijkste uiting.

Verworven hypogammaglobulinemie kan worden veroorzaakt door het gebruik van bepaalde medicatie (immunomodulerende medicatie als rituximab of bepaalde anti-epileptica). Andere oorzaken van secundaire hypogammaglobulinemie zijn aanmaakstoornissen van immunoglobulinen (leveraandoeningen, chronisch lymfatische leukemie of de ziekte van Kahler), of een verhoogd verlies van immuunglobulinen ten gevolge van bijvoorbeeld het nefrotisch syndroom of protein-losing-enteropathie.

De belangrijkste verwekkers van (met name luchtweg)infecties bij deze afweerstoornis zijn de gekapselde bacteriën (pneumokokken, Haemophilus influenzae en meningokokken). Deze pathogenen veroorzaken bij patiënten zonder gestoorde afweer ook infecties, maar bij een humorale afweer- stoornis is er sprake van recidiverende infecties met deze verwekkers of onverwacht ernstig beloop van de infectie.

Hardnekkige darminfecties veroorzaakt door Campylobacter jejuni en Giardia lamblia kunnen ook een aanwijzing zijn voor een gestoorde humorale afweer. Giardiasis kan malabsorptie veroorzaken, zich uitend in gewichtverlies en buikklachten.

\section{Therapie}

De behandeling van hypo- of agammaglobulinemie bestaat uit het toedienen van immuunglobulinen. De toediening kan intraveneus of subcutaan plaatsvinden. Beide toedieningsvormen kunnen in de thuissituatie plaatsvinden met de hulp van een speciaal thuiszorgteam. De hoeveelheid immuunglobuline in grammen alsook de regelmaat waarmee het gegeven wordt, verschilt per patiënt. In geval van intraveneuze toediening is de frequentie gemiddeld 1 maal per 3 tot 4 weken, bij subcutane toediening is deze wekelijks. Op geleide van het gewicht van de patiënt wordt de startdosering bepaald en op geleide van de IgG-bloedspiegel wordt de dosering aangepast. Aangezien het toegediende product humaan is, kunnen er bijwerkingen optreden tijdens de toediening. Frequente bijwerkingen tijdens de toediening zijn hoofdpijn, koorts, rillingen, duizeligheid, rugpijn, gewrichtspijn, misselijkheid, braken, en allergische reacties. Zelden treden de volgende ernstige verschijnselen op: hypotensie, anafylactische shock, aseptische meningitis, hemolytische anemie, nefrotoxiciteit, tromboembolische complicaties, TIA's, CVA's of eczematoïde huidafwijkingen.

\subsection{Stoornissen van de cellulaire afweer}

\section{Niet-specifiek: fagocyterende cellen}

Onder de fagocyten vallen de monocyten, neutrofiele en eosinofiele granulocyten. Een stoornis in de fagocytenfunctie kan gepaard gaan met infecties van huid en subcutane weefsels. Verder kunnen bij een kwantitatief tekort van neutrofiele granulocyten ernstige infecties optreden op diverse plaatsen in het lichaam. Deze stoornissen zijn zeer zeldzaam. Belangrijke verwekkers van infecties zijn: grampositieve kokken (Staphylococcus aureus), H. influenza, Candida sp, en Aspergillus spp.

Een voorbeeld van een aangeboren afwijking in fagocytose is chronische granulomateuze ziekte (CGD). Hierbij is het doden van pathogeen gestoord.

De meest voorkomende stoornis is neutropenie (< 500 granulocyten). Oorzaken van verworven neutropenie kunnen worden onderverdeeld in: 
- verminderde aanmaak van neutrofiele granulocyten ( bijv. medicamenteus (cytostatica), tekort aan bouwstoffen (vitamine $\mathrm{B}_{12}$ - en foliumzuurdeficiëntie) of beenmergaandoeningen als leukemie en myelofibrose;

- verhoogde afbraak van neutrofiele granulocyten (bijv. auto-immuunziekte);

- verhoogd verbruik van neutrofiele granulocyten door bijvoorbeeld hypersplenisme.

\section{Specifiek: T-lymfocyten en macrofagen}

Defecten van de specifieke cellulaire afweer kunnen het gevolg zijn van stoornissen van de T-lymfocyten en van de macrofagen.

Bij de volgende infecties en verwekkers moet gedacht worden aan een afwijking van de cellulaire immuniteit: herpessimplexvirus, varicellazostervirus, cytomegalovirus, Listeria monocytogenes, Salmonella sp, mycobacteriën, Nocardia sp, Candida spp, Cryptococcus neoformans, Pneumocystis jirovicii (voorheen carinii), Toxoplasma gondii.

Voorbeelden van een verworven stoornis van de cellulaire immuniteit zijn maligne lymfoproliferatieve aandoeningen, SLE, chronische nierinsufficiëntie, alcoholisme en levercirrose, ondervoeding, virale infecties als hiv, EBV, CMV en gebruik van bepaalde immuunsuppressiva (prednison, ciclosporine, methotrexaat). Het klassieke voorbeeld is echter de immuundeficiëntie die optreedt in het eindstadium van een hiv-infectie. Naast voorgaande stoornissen zijn er zeldzame aangeboren stoornissen van de cellulaire afweer. Deze stoornissen worden hier buiten beschouwing gelaten.

\section{Therapie}

De therapie bij een chronische afwijking in de specifieke cellulaire afweer bestaat voornamelijk uit antibioticaprofylaxe tegen de genoemde verwekkers.

\section{Infectie met humaan} immunodeficiëntievirus 1 (hiv-1)

Infectie met het humane immuundeficiëntievirus type 1 (hiv-1) is momenteel een van de grootste uitdagingen van de volksgezondheid. In tegenstelling tot het hiv-2-virus, dat vooral in West-Afrika voorkomt, is er bij hiv-1 sprake van een pandemie met wereldwijd ongeveer 34 miljoen geïnfecteerden.

Hiv-1 behoort tot de retroviridae, genus lentivirus. Transmissie vindt plaats via onbeschermd seksueel contact of bloed-bloedcontact. Hiv-1 infecteert de CD4 positieve cellen van het immuun- systeem, waaronder de CD4 positieve T-lymfocyten ('CD4-cellen') en leidt zoals hiervoor beschreven tot een stoornis van de cellulaire afweer. Infectie van een $\mathrm{CD}_{4}$ positieve cel begint met het binden van het hiv-1- envelopeiwit gp12o aan de CD4-receptor. Hierdoor ondergaat gp12o een conformatieverandering, als gevolg waarvan de variabele regio van gp12o vrij komt (V3), die nu kan binden aan een van de coreceptoren. $\mathrm{Na} \mathrm{CD} 4$ en coreceptorbinding maken nieuwe conformatieveranderingen in gp12o een door gp41 envelopeiwit gemedieerde fusie van het virion met de cel mogelijk. Dit proces wordt 'hiv entree' genoemd. Het genetisch materiaal van het hiv-1-virus bestaat uit RNA, dat door het enzym reverse transcriptase wordt omgezet in DNA dat vervolgens in het DNA van de gastheer wordt geïntegreerd door het enzym integrase. Vervolgens kan, via het eigen cellulaire apparaat, transcriptie van dit DNA plaatsvinden en kunnen nieuwe viruspartikels worden gegenereerd die weer andere (CD4 positieve) cellen kunnen infecteren. Het hiv1-virus kan gedurende lange tijd latent aanwezig zijn in de gastheercel.

$\mathrm{Na}$ infectie treedt er een geleidelijke daling op van het aantal CD4-cellen, de snelheid van daling varieert tussen patiënten. Waarschijnlijk is de chronische activatie van het immuunsysteem die optreedt bij patiënten met hiv-1-infectie de belangrijkste onderliggende oorzaak van het verlies van CD4-cellen.

\section{Acute infectie}

Primaire of acute hiv-infectie wordt gedefinieerd als de periode tussen de hiv-besmetting en het ontstaan van de chronische infectie en duurt ongeveer 3 tot 24 weken. Deze fase kan asymptomatisch verlopen of gepaard gaan met aspecifieke klachten (acuut retroviraal syndroom). Vaak voorkomende symptomen zijn koorts, spier-/gewrichtspijn, moeheid, malaise, keelpijn, opgezette lymfeklieren en huidafwijkingen. Maar ook zeldzamere complicaties, zoals een aseptische meningitis kunnen optreden.

In de acute fase daalt initieel het aantal CD4cellen, waarna vervolgens weer herstel optreedt.

\section{Chronische infectie}

Tijdens de chronische fase van de hiv-infectie daalt het aantal CD4-cellen geleidelijk. Kenmerkend voor de hiv-1 geïnfecteerde patiënt is het voorkomen van opportunistische infecties. Voorkomen en type van opportunistische infecties hangen af van het aantal CD4-cellen. Bij het opstellen van een differentiaaldiagnose van een acuut infectieus probleem bij een hiv-1 positieve patiënt is het daarom van elementair belang op de hoogte te zijn van het actuele aantal CD4-cellen. 


\begin{tabular}{|c|c|}
\hline Tabel 8.1 & $\begin{array}{l}\text { Relatie tussen het aantal CD4 } \\
\text { positieve T-lymfocyten en voor- } \\
\text { komen van opportunistische } \\
\text { infecties. }\end{array}$ \\
\hline $\begin{array}{l}\text { aantal } \\
C D_{4} \text {-cel- } \\
\text { len }\end{array}$ & $\begin{array}{l}\text { Voorbeelden van opportunistische } \\
\text { infectie }\end{array}$ \\
\hline$<50$ & $\begin{array}{l}\text { Mycobacterium avium complex, } \\
\text { CMV, cryptococcus }\end{array}$ \\
\hline $50-100$ & $\begin{array}{l}\text { Toxoplasma gondii, invasieve schim- } \\
\text { melinfecties }\end{array}$ \\
\hline$<200$ & $\begin{array}{l}\text { Pneumocystis jirrovicii, kaposi-sar- } \\
\text { coom, EBV-lymfoom }\end{array}$ \\
\hline$<300$ & tuberculose, Candida-infecties \\
\hline$<400$ & $\begin{array}{l}\text { reactivatie van herpes simplex en } \\
\text { herpes zoster }\end{array}$ \\
\hline
\end{tabular}

\section{Primaire profylaxe}

Indien de CD4-cellen lager dan 200 zijn, dient primaire profylaxe gegeven te worden ter preventie van Pneumocystis jirovicii infectie (<200 CD4-cellen). De therapie van keuze is lage dosis (48o mg) cotrimoxazol. Bij een groot aantal patiënten treedt echter na enkele weken een rash op waarschijnlijk door de hiv-geïnduceerde immuundisregulatie en wordt meestal overgegaan op maandelijkse verneveling met pentamidine.

\section{Diagnose}

Voor het stellen van de diagnose wordt naast het klinische beeld gebruikgemaakt van een aantal laboratoriumtechnieken. Tegenwoordig wordt meestal gebruikgemaakt van een gecombineerde test waarbij zowel antistoffen tegen hiv-1antigenen als het p24-antigeen aangetoond kunnen worden. Het voordeel hiervan is dat het p24antigeen sneller gemeten kan worden in de acute fase van de infectie, als er nog geen antistofproductie op gang is gekomen. Hierdoor kan er dus sneller informatie gegeven worden na een (potentieel) onveilig contact. Het is gebruikelijk om na een positieve uitslag van de combinatietest ter bevestiging een western blot te verrichten. De 'viral load' (het aantal viruskopieën) in het plasma kan worden bepaald, door middel van een 'reverse transcriptase polymerase chain reaction (RT-PCR)' assay. Voor het bepalen van het aantal CD4 positieve T-lymfocyten wordt gebruikgemaakt van flowcytometrie.

\section{Preventie}

Belangrijkste preventieve maatregel is het voorkomen van onveilig seksueel contact (condoom) of bloedcontact met een potentieel hiv-1 geïnfecteerd persoon.

Indien een dergelijk onveilig contact toch heeft plaatsgevonden, kan (na consultatie met een viroloog of een internist-infectioloog) post-exposure profylaxe (PEP) voorgeschreven worden. Momenteel bestaat deze behandeling uit 28 dagen combinatietherapie met antiretrovirale middelen. Omdat dit een behandeling is met veel potentiële bijwerkingen, is er een landelijke richtlijn hiervoor opgesteld. De laatste jaren wordt er (vooral in derdewereldlanden) veel onderzoek gedaan naar zgn. pre-exposure profylaxe (PrEP), bijvoorbeeld door middel van het innemen van antiretrovirale geneesmiddelen (tenofovir, emtricitabine) of toedienen van vaginale crèmes met een antiretrovirale werking voorafgaand aan seksueel contact. Alhoewel er inmiddels positieve resultaten zijn bereikt, is verder onderzoek noodzakelijk en heeft PrEP in Nederland nog geen vaste plaats verworven in de preventie van hiv-1-infectie.

\section{Specialistische therapie}

'Highly active antiretroviral therapy' (HAART)

Zie ook hoofdstuk 25 Antimicrobiële therapie.

Hiv-1-patiënten worden in Nederland behandeld in zogeheten hiv-behandelcentra, waar er momenteel 25 (volwassenen) van zijn en 4 kindercentra (AMC, UMCG, Sophia EMC en Wilhelmina Kinderziekenhuis, UMCU). De behandeling bestaat uit het voorschrijven van 'highly active antiretroviral therapy' (HAART), ook wel combinatie antiretrovirale therapie (cART) genoemd. Dit houdt in dat er behandeld wordt met een combinatie van meerdere (minimaal 3) antiretrovirale geneesmiddelen. De gedachte hierachter is, dat op deze manier de kans dat resistentie van het hiv-1-virus tegen antiretrovirale middelen optreedt minder groot is.

Momenteel zijn er vijf klassen antiretrovirale geneesmiddelen: remmers van het enzym reverse transcriptase (nucleos(t)ide revers transcriptase inhibitors (NRTI) en non-nucleoside reverse transcriptase inhibitors (NNRTI)), remmers van het integrase enzym (integraseremmers), remmers van het protease-enzym (proteaseremmers) en remmers van hiv-entree in de cel (CCR5 coreceptor antagonisten en fusieremmers). 
Door de jaren heen zijn de bijwerkingen en de hoeveelheid tabletten die moeten worden ingenomen afgenomen. Belangrijkste bijwerkingen zijn metabole complicaties, zoals afwijkingen van de gemeten lipiden in het bloed, stoornissen in de vetverdeling over het lichaam (zich uitend in lipoatrofie dan wel -dystrofie) en gastro-intestinale klachten.

Doel van de behandeling is het bereiken van langdurige suppressie van de viral load (ondetecteerbare viral load beneden de 50 kopieën/ml) en herstel van het immuunsysteem door stijging van het aantal CD4-cellen tot normale waarden.

Waar tot voor kort pas gestart werd met HAART in een gevorderd stadium van de ziekte, zijn er nu steeds meer aanwijzingen dat het beter is om eerder te starten. In Nederland wordt momenteel geadviseerd in ieder geval te starten beneden de 350 CD4-cellen en op individuele basis kan overwogen worden te starten tussen de 350-500 CD4-cellen. Er is een aantal indicaties voor het starten van HAART ongeacht het aantal CD4-cellen, zoals zwangerschap, hiv-geassocieerde neuropathie en hepatitisB-virus co-infectie met een behandelindicatie. De duur van de behandeling is levenslang; het hiv-1virus kan latent aanwezig blijven in CD4-cellen, onbereikbaar voor antiretrovirale therapie.

$\mathrm{Er}$ is momenteel veel aandacht voor de versnelde veroudering die mede onder invloed van het hivvirus zou optreden. De belangrijkste verschijnselen zijn toegenomen prevalentie van hart- en vaatziekten, botontkalking en geheugenverlies.

Resistentie Hiv-1-virus is een snel replicerend virus waarbij veel mutaties voorkomen. Daarom is er in elke patiënt een grote hoeveelheid van verschillende hiv-1-varianten aanwezig. Hier schuilt het gevaar van resistentie tegen antiretrovirale middelen. $\mathrm{Er}$ is een duidelijke bewezen relatie tussen therapietrouw van de patiënt en het optreden van resistentie. Als er sprake is van suboptimale spiegels in het bloed dan kan een hiv-1-variant die ongevoelig is voor deze geneesmiddelen repliceren, wat kan leiden tot een toename van de viral load (virologisch falen). Om vervolgens deze patiënt weer succesvol te behandelen moet er een nieuwe combinatie antiretrovirale middelen gezocht worden, werkzaam tegen dit resistente hiv-1-virus.

Prognose Sinds de introductie van HAART in 1996 is de prognose van patiënten geïnfecteerd met het hiv-1-virus sterk verbeterd, zodanig dat de mortaliteit vergelijkbaar lijkt met die van andere chronische ziekten (zoals diabetes mellitus). In het algemeen lijkt de mortaliteit echter nog steeds hoger te zijn dan die van de algehele populatie. Er zijn namelijk steeds meer aanwijzingen dat er bij patiën- ten geïnfecteerd met hiv een versneld verouderingsproces gaande is, met een verhoogde incidentie van bijvoorbeeld cardiovasculaire aandoeningen en maligniteiten als gevolg. Voor de arts houdt dit in dat - in tegenstelling tot de beginjaren van de pandemie - de preventie en het managen van deze langetermijncomplicaties op de voorgrond staan.

\section{5}

\section{Infectieuze diarree}

Zie ook hoofdstuk 10 Kindergeneeskunde en 12 Maag-, darm- en leverziekten.

Acute diarree komt zeer frequent voor en maar een klein deel van de patiënten raadpleegt een arts. In ongeveer $40 \%$ van de gevallen kan een verwekker worden aangetoond. Virale verwekkers komen het vaakst voor: bij volwassenen zijn de norovirussen de belangrijkste verwekkers, bij jonge kinderen de rotavirussen. De meest voorkomende bacteriële verwekkers zijn Salmonella, Campylobacter en Shigella. Het eten van besmet voedsel kan leiden tot een darminfectie met E. coli. Dit gebeurt nogal eens tijdens reizen in het buitenland. Parasitaire infecties zijn slechts zelden de oorzaak van diarree. Bij kinderen kan Giardia lamblia diarree geven, in tropische landen dient uiteraard rekening te worden gehouden met amoebiasis.

Veruit de meeste darminfecties gaan vanzelf over en behoeven geen specifieke diagnostiek of therapie.

\section{Diagnostiek}

De belangrijkste complicatie bij darminfecties is uitdroging. Met het oog daarop dient de inname van vocht, de frequentie van diarree, eventueel braken en de urineproductie goed te worden nagevraagd. Zoals bekend zijn een slechte huidturgor, verwardheid, duidelijk verminderde urineproductie en neiging tot collaps tekenen van uitdroging. Bij bloed en slijm bij de ontlasting, aanhoudende koorts en bij patiënten met een verminderde weerstand dient rekening te worden gehouden met een gecompliceerd beloop. Bij deze groepen patiënten dient ook sneller nader onderzoek, een feceskweek, te worden ingezet. Dit geldt ook voor patiënten die in de levensmiddelenindustrie of de horeca werken.

De klassieke feceskweken worden geleidelijk aan vervangen door moleculaire testen (PCR) en enzymatisch (ELISA-)onderzoek op feces. 
In de allereerste plaats is goede voorlichting nodig over het voorkomen en behandelen van dehydratie door voldoende vochtinname en het gebruik van ORS: $10-20 \mathrm{ml} / \mathrm{kg} / \mathrm{uur}$, te bereiden volgens de gebruiksaanwijzing. Medicamenteuze behandeling is zoals al gezegd slechts bij hoge uitzondering noodzakelijk: antimicrobiële behandeling geschiedt dan op geleide van de kweek en in overleg met een infectioloog. Bij ernstige ziekteverschijnselen kan zonder diagnose een driedaagse behandeling met azitromycine worden overwogen. Een Giardiainfectie kan eventueel met metronidazol worden behandeld.

\subsection{Luchtweginfecties}

Zie ook hoofdstuk 11 Longziekten.

De volgende luchtweginfecties worden hierna zeer kort besproken: otitis media, acute rinosinusitis, acute faryngitis en tonsillitis, acute bronchitis en pneumonie. Voor een uitgebreidere bespreking kan men de desbetreffende NHG-Standaarden raadplegen.

Otitis media is een infectie van het middenoor waarbij in ongeveer de helft van de gevallen een bacteriële verwekker kan worden aangetoond en die vooral bij kinderen voorkomt. De aandoening is in het overgrote deel van de gevallen self-limiting en duurt ongeveer een week. Na twee tot drie dagen nemen de klachten meestal al af.

Acute rinosinusitis is een ontsteking van het neusslijmvlies en de bijholten. Hoe vaak er sprake is van een bacteriële infectie is niet helemaal duidelijk, waarschijnlijk in ongeveer $30 \%$ van de gevallen. Het natuurlijk beloop varieert van één tot drie weken.

Acute faryngitis en/of tonsillitis is in gemiddeld $30 \%$ van de gevallen een bacteriële infectie (hemolytische streptokokken) en duurt ongeacht de verwekker ongeveer zeven tot tien dagen.

Acute bronchitis is een ontsteking van de lagere luchtwegen. Een onderscheid tussen tracheïtis en bronchitis is op klinische gronden niet te maken. In ongeveer $20 \%$ van de gevallen is een bacteriële verwekker aan te tonen. (met name Streptococcus pneumoniae en Haemophilus influenzae). Het natuurlijk beloop is tussen de één en drie weken.

Bij pneumonie kan in ongeveer de helft van de patiënten een bacteriële verwekker worden aangetoond. Het natuurlijk beloop is niet goed bekend, omdat er slechts zelden afgewacht wordt.
De diagnostiek van otitis media berust op anamnese (oorpijn, koorts) en lichamelijk onderzoek (rood bomberend trommelvlies).

De diagnostiek van rinosinusitis berust voornamelijk op de aanwezigheid van klachten van neus en bijholten. Aanvullend onderzoek, bijvoorbeeld röntgenonderzoek, heeft geen toegevoegde waarde!

Bij faryngitis en tonsillitis wijzen koorts, beslag op de tonsillen, gezwollen klieren in de hals, en de afwezigheid van hoest op een bacteriële infectie. Als deze vier symptomen aanwezigheid zijn, is de kans op een bacteriële infectie ongeveer 50-60\%. Gebruik van een van de sneltests die de aanwezigheid van een hemolytische streptokok type A goed kan aantonen of uitsluiten (positief en negatief voorspellende waarde ongeveer 90\%) kan een toegevoegde waarde hebben, maar daarbij moeten wel enkele kanttekeningen worden gemaakt. Ten eerste wordt ongeveer $25 \%$ van de bacteriële infecties veroorzaakt door andere dan type-A-streptokokken, die niet door de test kunnen worden gedetecteerd. Ten tweede is de winst van antimicrobiële behandeling bij bacteriële keelinfecties beperkt: een à twee dagen korter klachten.

Bij lagere luchtweginfecties is met name van belang een onderscheid te maken tussen acute bronchitis en pneumonie. Dit is op grond van klachten en symptomen moeilijk. Het probleem is dat enkele symptomen, zoals koorts, tachypnoe, tachycardie, hypotensie, verwardheid en eenzijdige afwijkingen bij auscultatie en percussie wel enige positief voorspellende waarde hebben, dat wil zeggen dat als deze afwijkingen aanwezig zijn de kans op pneumonie is verhoogd, maar afwezigheid van deze afwijkingen sluiten een pneumonie niet uit. Twee recente studies lieten zien dat het meten van C-reactive protein (CRP) in capillair bloed wel toegevoegde waarde had. Met name lage waarden, dat wil zeggen $<20 \mathrm{mg} / \mathrm{ml}$, sluiten een pneumonie vrijwel uit.

\section{Therapie}

De indicaties voor antimicrobiële therapie bij middenoorontsteking zijn met name gebaseerd op een recente zogeheten individuele meta-analyse, waarin de gegevens van alle beschikbare studies werden samengevoegd en opnieuw werden geanalyseerd. Daarbij werd gezien dat kinderen jonger dan twee jaar met dubbelzijdige otitis en kinderen met een loopoor bij het eerste contact baat hadden bij antimicrobiële behandeling. Daarnaast dienen kinderen met een verhoogde kans op complicaties 
te worden behandeld, met name kinderen jonger dan zes maanden, kinderen met aangeboren of verworven anatomische afwijkingen en kinderen met een gestoorde afweer. Over de indicaties van antibiotica bij volwassenen is weinig bekend. Als algemene stelregel geldt dat een volwassene met middenoorontsteking behandeld moet worden met een antibioticum.

Neusdruppels hebben bij kinderen met middenoorontsteking geen effect op de oorontsteking. Vaak wordt te weinig pijnstilling gegeven aan kinderen met oorpijn; paracetamol, $10 \mathrm{mg}$ per $\mathrm{kg}$ lichaamsgewicht 4-6 dd oraal of 3-4 dd rectaal zorgt voor een redelijk tot goede pijnstilling. Als een kind regelmatig pijn aangeeft, ook overdag, is gewoon om de 4 tot 6 uur toedienen beter dan alleen toedienen als het kind pijn aangeeft!

Bij rinosinusitis bij verder gezonde volwassenen zijn er geen aanwijzingen dat antibiotica een relevant effect hebben, ook niet als de klachten langer dan een week bestaan. Ook intranasale corticosteroïden lijken geen effect te hebben. Complicaties treden slechts zeer zelden op, daarom is een afwachtend beleid en adequate pijnstilling aangewezen. Alleen bij patiënten met een gestoorde afweer, met ernstige ziekteverschijnselen en met recidiverende klachten hebben antibiotica wellicht effect. Als er een antibioticum wordt voorgeschreven, dan is doxycycline of amoxicilline een goede keuze.

Bij acute keelontsteking hebben zoals gezegd antibiotica slechts een beperkt effect. Gezien de goede gevoeligheid van alle typen bètahemolytische streptokokken is een smalspectrumpenicilline, bijvoorbeeld feniticilline, eerste keuze.

Bij gezonde volwassenen met acute bronchitis heeft antimicrobiële behandeling geen relevant effect. De indicaties, zoals verwoord in de gangbare richtlijnen (NHG en SWAB) zijn gebaseerd op het risico op complicaties bij bepaalde groepen patiënten en gestoeld op inschattingen van experts. Er bestaan geen goede studies bij risicopatiënten zoals jonge kinderen en ouderen. Over het algemeen wordt aangeraden om behandeling met een antibioticum te overwegen bij heel jonge kinderen en ouderen, met name als zij duidelijke symptomen hebben zoals benauwdheid en koorts en wanneer zij lijden aan chronische aandoeningen zoals COPD, hartfalen of diabetes mellitus. Bij twijfel over de aanwezigheid van een pneumonie kan een CRP-test worden overwogen. Een waarde onder de $20 \mathrm{mg} / \mathrm{l} \mathrm{maakt} \mathrm{de} \mathrm{aanwezigheid} \mathrm{van} \mathrm{pneumonie} \mathrm{bij}$ matig zieke patiënten onwaarschijnlijk, bij waarden boven de 100 is de kans op pneumonie verhoogd. Doxycycline en amoxicilline zijn eerstekeuze preparaten. Doxycycline heeft als nadeel dat in Nederland ongeveer 10\% van de pneumokokken hiertegen resistent is. Amoxicilline kent nauwelijks resistentie bij pneumokokken, maar van de in Nederland bekende Haemophilus influenzae stammen is wel ongeveer $15 \%$ resistent tegen dit middel. Rekening houden met Mycoplasma als verwekker is niet nodig, zo is uit verschillende studies gebleken. Deze verwekker komt in kleine epidemieën voor en heeft gemiddeld genomen een mild verloop.

\subsection{Neonatale infecties}

Zie hoofdstuk 1o Kindergeneeskunde.

\subsection{Urineweginfecties}

Zie ook hoofdstuk 13 Nierziekten en 21 Urologie. Als definitie van een urineweginfectie wordt meestal gehanteerd: de aanwezigheid van klachten en ten minste $10^{3}$ bacteriën per $\mathrm{ml}$ vers geloosde urine. In de NHG-Standaard wordt als grens $10^{5}$ aangehouden, maar wel wordt in de voetnoten aangegeven dat een lager aantal bacteriën waarschijnlijk ook klinisch relevant is. Asymptomatische bacteriurie komt voor bij $1 \%$ van de kinderen en mannen en $5 \%$ van volwassen vrouwen. Bij bejaarden komt asymptomatische bacteriurie veel vaker voor (tot 50\%). Klachten bij een urineweginfectie zijn pijn en/of branderig gevoel bij plassen, frequente mictie, loze aandrang, bloed bij de urine, koorts, pijn in de onderbuik, pijn in de rug, pijn in de zij.

Het overgrote deel van de bacteriële infecties wordt veroorzaakt door E. coli.

\section{Diagnostiek}

Pijnlijke frequente mictie duidt bij volwassen vrouwen in 50 tot $90 \%$ van de gevallen op een daadwerkelijke infectie. Met name vrouwen die al eerder aangetoonde infecties hebben gehad, blijken een nieuwe infectie goed te kunnen inschatten. Aanvullend onderzoek kan in die gevallen dus achterwege blijven.

Voor aanvullend onderzoek is verse urine nodig, dat wil zeggen urine die korter dan een half uur voor onderzoek is geloosd. Eventueel kan eerder opgevangen urine in een schoon potje in de ijskast worden bewaard. Extra maatregelen als opvangen van midstream urine of het wassen en of spreiden van de labia hebben geen toegevoegde waarde. De patiënt moet niet korter dan twee uur voor het produceren van de urine hebben geplast.

Een positieve nitriettest in combinatie met klachten betekent dat de kans dat er een echte bacteriële 
infectie met nitraatomzettende bacteriën (zoals E. coli) aanwezig is ongeveer $80-90 \%$ bedraagt. Bij symptomatische vrouwen met een negatieve nitriettest heeft nog altijd ongeveer $40 \%$ een infectie. In dat geval dient een kweek te worden verricht. De in Nederland gebruikte dipslide tests zijn daarvoor voldoende betrouwbaar en goed toepasbaar. Zowel de positieve als negatieve uitkomsten geven ongeveer $90 \%$ zekerheid omtrent aan- of afwezigheid van een infectie. Kweek met resistentiebepaling dient altijd te worden verricht bij kinderen, zwangeren, mannen en bij volwassen vrouwen met een mogelijke pyelonefritis of persisterende klachten na behandeling.

De leukotest (een teststrip zoals de nitriettest) heeft weinig toegevoegde waarde naast de nitriettest. Het sediment is bewerkelijk en de betrouwbaarheid is erg afhankelijk van uitvoering en beoordelaar.

Screening op asymptomatische bacteriurie heeft geen zin, ook niet bij zwangeren.

\section{Therapie}

De keuze voor een antibioticum hangt af van bacteriële resistentie, ernst van de infectie en, in laatste instantie, kosten. Vanwege resistentie zijn trimethoprim (ongeveer 20\%) en amoxicilline (meer dan $30 \%$ ) geen middelen meer van eerste keuze. Bij de behandeling van ongecompliceerde infecties bij volwassen vrouwen is nitrofurantoïne ( $2 \mathrm{dd} 100$ mg, 5 dagen) eerste keuze. Ook bij meisjes ouder dan vier jaar, jongens ouder dan 12 en mannen die geen koorts hebben of andere klachten die wijzen op een prostatitis of pyelonefritis kan in eerste instantie nitrofurantoïne worden voorgeschreven, de NHG-Standaard adviseert bij deze groepen wel 7 in plaats van 5 dagen te behandelen. Ook bij patiënten met diabetes mellitus wordt geadviseerd zeven dagen te behandelen bij een ongecompliceerde infectie. Nitrofurantoïne mag niet meer worden gebruikt als de bevalling binnen een week wordt verwacht. Bij alle hier niet genoemde groepen, dus bij meisjes van 4 jaar of jonger, jongens jonger dan 12, en patiënten met tekenen van weefselinvasie (pyelonefritis, prostatitis) dient amoxicilline met clavulaanzuur of, bij intolerantie voor amoxicilline met clavulaanzuur, co-trimoxazol (2 dd $960 \mathrm{mg}$ niet bij ouderen!) of een fluoroquinolon (norfloxacine $2 \mathrm{dd}$ $400 \mathrm{mg}$ of ciprofloxacine $2 \mathrm{dd} 500 \mathrm{mg}$ ) te worden voorgeschreven gedurende tien dagen.

Fosfomycine lijkt een goed alternatief bij ongecompliceerde infecties bij vrouwen.

Bij urineweginfecties bij mannen, kinderen en zwangeren dient na de behandeling ter controle een dipslide te worden verricht. Ook dient verwij- zing voor nadere diagnostiek te worden overwogen bij deze patiënten. Volgens de NHG-Standaard kan bij mannen één ongecompliceerde infectie na succesvolle behandeling nog worden afgewacht. Kinderen jonger dan 6 maanden dienen direct te worden doorgestuurd.

\section{9}

\section{Zoönosen}

Een zoönose is een ziekte die van dier op mens kan overgaan of andersom. Mensen komen op diverse manieren in contact met dieren. Zo heeft $55 \%$ van de Nederlandse gezinnen één of meer huisdieren, zijn er voedselproducerende landbouwhuisdieren en komen mensen in contact met dieren in het wild.

Veel van de nieuwe ziektebeelden waarmee we te maken krijgen, zijn zoönosen. Voorbeelden uit het recente verleden zijn de SARS-epidemie in 2003 door contact met civetkatten. Maar ook infecties met het hepatitis-E-virus berusten op contact met dieren of dierlijk materiaal.

Een in Nederland veelvoorkomende zoönose is kattenkrabziekte, en in 2010 hebben de opkomende zoönosen Q-koorts en de Mexicaanse griep voor veel onrust gezorgd. Deze laatste drie worden hier kort besproken.

\section{Kattenkrabziekte}

Kattenkrabziekte wordt veroorzaakt door Bartonella henselae. De bacterie is moeilijk te kweken en groeit alleen op specifieke voedingsbodems.

Wanneer de mens geïnfecteerd wordt, ontstaat op de plek van de krab of de beet na drie tot zes dagen een laesie, die na enkele dagen geneest. Een derde van de patiënten heeft lichte koorts, hoofdpijn en algemene malaise. Eén tot twee weken na de primaire laesie ontwikkelt zich een regionale lymfadenitis (hals, oksel, lies), waarbij meestal één maar soms ook meerdere lymfeklieren zijn aangetast. De lymfeklieren zijn groot, zacht en gevoelig en draineren soms naar de oppervlakte. Na enkele weken neemt de lymfadenitis over het algemeen af en geneest spontaan, ook zonder behandeling. Ongeveer $2 \%$ van geïnfecteerde patiënten heeft een ooginfectie met conjunctivitis, lymfeklierzwelling en koorts (parinaud oculoglandulair syndroom). Enkele patiënten (1 tot $3 \%$ ) kunnen een meer gecompliceerd verloop vertonen, met onder andere ontstekingshaarden in bot (osteomyelitis), hart (endocarditis), lever, milt of long en zelfs uitbreiding naar het centrale zenuwstelsel. Deze beelden worden voornamelijk gevonden bij patiënten met een verzwakte afweer. 


\section{Diagnostiek}

IgM- en IgG-antistoffen in serum zijn aan te tonen met ELISA- of immunofluorescentietechnieken.

IgG-antistoffen zijn echter ook bij een deel van de gezonde mensen aantoonbaar en zijn daardoor minder goed bruikbaar voor het stellen van de diagnose. De meest gevoelige methode voor antigeendetectie is de PCR op pus en biopsiemateriaal.

\section{Therapie}

Bij ontstoken lymfeklieren heeft behandeling met antibiotica bij immuuncompetente patiënten meestal weinig effect en is de ziekte uiteindelijk zelflimiterend. Het verwijderen van pus uit de opgezette klieren leidt tot verlichting en verkort de duur van de klachten. Bij immuungecompromitteerde patiënten is de infectie niet zelflimiterend, maar reageert over het algemeen goed op antibiotica. De middelen van eerste keuze zijn op dit moment doxycycline of een van de macroliden.

\section{Q-koorts}

Q-koorts, een infectie veroorzaakt door de kleine obligaat intracellulaire bacterie Coxiella burnetii, komt in Nederland sinds lang sporadisch voor vanuit contact met dieren. Ongeveer $2 \%$ van de bevolking had antistoffen. Sinds 2007 blijkt in NoordBrabant en Gelderland echter sprake te zijn van massale besmetting en overdracht naar de bevolking vanuit voornamelijk melkgeiten- en melkschapenhouderijen.

In 2009 zijn er ruim 2.350 gevallen gemeld, zes patiënten overleden aan de ziekte. In 2010 waren er 504 gevallen en in 2011 nog ruim 80.

Door ruiming en vaccinatie lijkt de epidemie over zijn hoogtepunt heen. Wel worden er nu meer patiënten gevonden met chronische Q-koorts. Men moet hierop met name bedacht zijn bij patiënten met hartafwijkingen en/of vaatprothesen.

De actuele verspreiding is te vinden op www.rivm.nl.

\section{Ziektebeelden}

$\mathrm{Na}$ inhalatie van de bacterie ontstaat een ontsteking die meestal (in 6o\% van de gevallen) symptoomloos verloopt. Afhankelijk van de gezondheidstoestand van de patiënt, virulentie van de pathogeen, transmissieroute en grootte van het inoculum breidt de infectie zich uit en ontstaan er symptomen. De incubatietijd bedraagt meestal twee tot drie weken, maar extremen van 3 tot 30 dagen zijn gemeld. We onderscheiden acute Q-koorts en een chronische vorm.

De infectie kan leiden tot een pneumonie met soms ernstige algemene ziekte en ook hepatitis. Soms ontstaat bovendien een chronische Q-koorts met vooral cardiale problemen.

\section{Diagnostiek}

De diagnose is meestal gebaseerd op het aantonen van antistoffen. Ook de polymerase chain reaction (PCR) wordt steeds meer gebruikt, maar is voornamelijk positief in de eerste week van de acute ziekte of bij endocarditis.

\section{Therapie}

Q-koorts is meestal een zelflimiterende milde ziekte waarvoor geen therapie nodig is, tenzij er sprake is van een onderliggende ziekte. Voor de acute Q-koorts is doxycycline het middel van eerste keuze, Moxifloxacine kan ook worden gebruikt. Tijdens de zwangerschap wordt langdurig cotrimoxazol voorgeschreven. Bij chronische infecties, zoals endocarditis, wordt behandeld met een combinatie van geneesmiddelen gedurende ten minste anderhalf jaar of met moxifloxacine.

Bij verdenking op deze infectie lijkt verwijzing naar een centrum met veel ervaring of een afdeling Infectieziekten aangewezen.

Mexicaanse griep

Influenzavirussen behoren tot de familie van de Orthomyxoviridae en worden op basis van antigene, genetische en structurele verschillen onderverdeeld in drie typen: influenza $A$, influenza $B$ en influenza C. Influenza A en B zijn voor de mens de belangrijkste.

In 2009 verscheen een nieuw pandemisch virus, het 'nieuwe H1N1-virus' (de 'Mexicaanse griep'). Dit virus is ontstaan door een recente uitwisseling van genen tussen twee verschillende varkensgriepvirussen die elk eerder ófwel rechtstreeks afkomstig waren van een aviair (vogel)virus, ófwel het resultaat waren van uitwisseling van genen tussen menselijke, aviaire en varkensgriepvirussen.

Het nieuwe H1N1-virus heeft zich in 2009 razendsnel over de gehele wereld verspreid en aanleiding gegeven tot een relatief milde pandemie.

Preventie en therapie

De besmettingsweg voor nieuwe influenza-A (H1N1) is niet anders dan voor de seizoensin- 
fluenza. Influenzavirussen worden voornamelijk via druppeltjes van mens tot mens overgedragen: de geïnfecteerde persoon verspreidt door hoesten of niezen virushoudende druppeltjes in de omringende lucht, die door een potentieel slachtoffer wordt ingeademd. Kleine deeltjes met een diameter van 1 tot 5 microm lijken het meest effectief. De minimale aerogene besmettingsdosis is zeer laag, waarschijnlijk in de orde van één of enkele virusdeeltjes. Indirecte besmetting via besmette handen of voorwerpen (deurknoppen, telefoonhoorns, toetsenborden) speelt een kleinere rol dan het direct aanhoesten. Besmetting vindt meestal plaats in besloten ruimten; in de open lucht verspreidt het virus zich snel door de wind en het neerslaan van aerosolen, waardoor de kans op besmetting afneemt.

Voor de preventie en behandeling van influenza zijn neuraminidaseremmers beschikbaar. Dit zijn stoffen die specifiek de activiteit van het influenzavirale membraanenzym neuraminidase remmen, waardoor de verspreiding van nieuwe virusdeeltjes in de luchtwegen wordt belemmerd. Het nieuwe influenz- A- (H1N1-)virus is gevoelig voor de neuraminidaseremmers oseltamivir (Tamiflu ${ }^{\circledR}$ ) en zanamivir (Relenza ${ }^{\circledR}$ ), maar resistent tegen de M2ionkanaalblokkers amantadine en rimantadine.

\subsection{Virale hepatitis}

Zie ook hoofdstuk 12 Maag-, darm- en leverziekten.

Er zijn meerdere hepatitisvirussen. Op diagnostisch en therapeutisch gebied zijn enorme ontwikkelingen gaande betreffende hepatitis-B en hepatitis-C. In Nederland zijn vooral infecties met het hepatitis-A-virus (HAV), het hepatitis-B-virus (HBV) en het hepatitis-C-virus (HCV) oorzaken van virushepatitis. Daarom bespreken we alleen HAV, HBV en HCV.

Door immigratie, toename van het internationale reizigersverkeer en gerichte voorlichtingscampagnes van de overheid, zal de huisarts in toenemende mate te maken krijgen met vragen over preventie en diagnostiek van virushepatitis. Goede samenwerking tussen huisartsen, maag-darmleverartsen of internist-infectiologen en GGD's is van belang om tot optimale voorlichting te komen aan en behandeling van deze patiënten.

Wereldwijd zijn meer dan twee miljard mensen in contact geweest met het hepatitis-B-virus (HBV) en ongeveer 400 miljoen mensen zijn chronisch geïnfecteerd. Jaarlijks sterven meer dan 500.000 mensen aan HBV-geassocieerde leverziekte, voornamelijk door cirrose of een hepatocellulair carcinoom (HCC). In Nederland is een HBV-infectie re- latief zeldzaam. Naar schatting is in Nederland ongeveer $0,2 \%$ van de bevolking chronische drager van het virus en heeft 2,1\% een HBV-infectie doorgemaakt. In Nederland hebben naar schatting 75.00o mensen een chronische hepatitis B, waarvan ruim $30 \%$ een actieve chronische hepatitis is die voor behandeling in aanmerking komt.

Er zijn bevolkingsgroepen waarin $\mathrm{HBV} / \mathrm{HCV}$ infectie frequenter voorkomt, bijvoorbeeld bij immigranten uit het Midden-Oosten (HCV), Azië (HBV) mannen die seks hebben met mannen (HBV en $\mathrm{HCV}$ ), ooit intraveneus druggebruik (HCV) en bij mensen met wisselende seksuele partners (HBV).

De prevalentie van HCV in de algemene bevolking is onbekend, maar wordt geschat op o,3-0,4\%. De prevalentie van HCV-antistoffen in Nederland bij personen van allochtone herkomst komt vermoedelijk overeen met de gevonden prevalentie in het land van herkomst (Marokko, Turkije, Afrika bezuiden de Sahara). De prevalentie van anti-HCVantistoffen bij injecterende drugsgebruikers loopt, afhankelijk van de duur van de periode van injecterend drugsgebruik, op tot $70-80 \%$. Ook onder nietinjecterende drugsgebruikers is de HCVprevalentie hoog: 10-15\%. Van de Nederlandse hemofiliepatiënten heeft meer dan de helft anti-HCVantistoffen. Van de 4.000 dialysepatiënten heeft ongeveer $3 \%$ antistoffen.

\section{Diagnostiek}

Bij verdenking op een acute (virus)hepatitis zal dit eerst bevestigd moeten worden door het bepalen van afwijkende transaminasen (ALT, zie tabel 8.2 en figuur 8.1). Meestal bestaat bij een acute hepatitis ook icterus. Zijn er (bij routinematig onderzoek gevonden) licht verhoogde transaminasewaarden (ALAT en ASAT anderhalf- tot vijfmaal de bovengrens van normaal; recent zijn de normaalwaarden naar beneden bijgesteld tot voor een man: $<30 \mathrm{IU} /$ $\mathrm{ml}$ en voor een vrouw $<19 \mathrm{IU} / \mathrm{ml}$ ), dan worden deze na ongeveer vier weken opnieuw bepaald. Zijn de waarden nog steeds verhoogd, dan neemt de huisarts een anamnese af met specifieke aandacht voor gebruik van geneesmiddelen, alcohol en drugs, verricht lichamelijk onderzoek gericht op de meest voorkomende oorzaken van leverschade en verricht aanvullend onderzoek gericht op hepatitis B en C bij personen behorende tot een risicogroep. Risicogroepen voor een virushepatitis zijn:

- patiënten met icterus bij wie geen verdenking bestaat op pathologie van de galblaas of galwegen of een maligniteit; - patiënten met algemene malaise bij wie tevens verdenking bestaat op virushepatitis omdat: 
- zij behoren tot een risicogroep (zie boven) voor deze aandoening; of

- er een risicocontact is geweest voor virushepatitis; of

- zij eerder hepatitis-B of -C doormaakten. Als bij vermoeden van acute virushepatitis de HAV-, HBV- en HCV-serologie negatief uitvalt, wordt het onderzoek alsnog uitgebreid naar andere vormen van acute hepatitis, zoals CMV-infectie, ziekte van Pfeiffer en HEV. Wel moet men zich realiseren dat vroeg in de ziekte de serologie nog negatief kan zijn (zie HCV hierna). Sinds kort komt hepatitis-E, behalve als importziekte (met name uit India, Pakistan en Bangladesh), in Nederland ook endemisch voor. Deze besmetting is geassocieerd met het eten van varkensvlees en wild zwijn. Indien er serologisch geen aanwijzingen zijn voor een virale hepatitis en alcohol, geneesmiddelen of

\begin{tabular}{|c|c|}
\hline Tabel 8.2 & $\begin{array}{l}\text { Serologische diagnostiek bij } \\
\text { verdenking op virushepatitis. }\end{array}$ \\
\hline hepatitis-A & ALAT, IgM-anti-HAV \\
\hline \multirow[t]{3}{*}{ hepatitis-B } & ALAT en HBsAg \\
\hline & $\begin{array}{l}\text { als } \mathrm{HBsAg} \text { negatief is bij een patiënt } \\
\text { die tot voor kort icterisch was: IgM- } \\
\text { anti-HBc }\end{array}$ \\
\hline & $\begin{array}{l}\text { als HBsAg positief is bij een patiënt } \\
\text { zonder klachten/symptomen: } \\
\text { HBeAg en ALAT }\end{array}$ \\
\hline hepatitis-C & ALAT en anti-HCV* \\
\hline hepatitis-E & ALAT, IgM-anti-HEV \\
\hline
\end{tabular}

\footnotetext{
* Bij acute hepatitis-C kan de anti-HCV tot circa zes maanden na besmetting negatief zijn. Indien er een reële kans bestaat op acute hepatitis-C (bekende HCVpositieve bron), dan moet overleg plaatsvinden met een maag-darm-leverarts of internist-infectioloog over bepaling van het HCV-RNA. HCV-RNA is in vrijwel 100\% van de gevallen binnen enkele weken na besmetting positief. Een alternatief is om na één, drie en zes maanden het anti-HCV te herhalen, het nadeel is wel dat behandeling van acute HCV een veel betere prognose heeft dan behandeling van chronische HCV en dit op de laatste manier wordt gemist.
}

drugs niet de oorzaak lijken, dan vraagt de huisarts een echografie aan van de lever met de vraag of er steatosis hepatis bestaat.

\section{Vervolgbeleid}

Voor acute virushepatitis A en C, en voor acute en chronische virushepatitis $\mathrm{B}$ en $\mathrm{C}$ geldt aangifteplicht. Voor HEV geldt geen aangifteplicht. Zie voor de specifieke meldingscriteria per infectieziekte:

http://www.rivm.nl/cib/themas/wetgeving/. De NHG-richtlijn geeft de volgende adviezen:

-Bij patiënten met acute hepatitis $\mathrm{B}$, bij wie HBsAg is aangetoond, laat de huisarts na zes maanden opnieuw het HBsAg bepalen. De huisarts kan er ook voor kiezen deze patiënt door te verwijzen naar de specialist. Wanneer het HBsAg na zes maanden nog steeds aanwezig is, is er sprake van een chronische hepatitis B en bepaalt de huisarts HBeAg en ALAT. Is vervolgens het HBeAg negatief en het ALAT normaal, dan is het om chronische ontsteking definitief uit te sluiten noodzakelijk om jaarlijks gedurende drie jaar te controleren op de aanwezigheid van HBsAg en ontstekingsactiviteit in de lever (verhoging van ALAT).

- Is het HBeAg positief en/of het ALAT verhoogd, dan is er een chronische actieve ontsteking van de lever. Deze patiënten worden verwezen naar een maag-darm-leverarts, met specifieke belangstelling voor leverziekten of naar een internist-infectioloog.

- Is bij een negatief HBeAg het ALAT gedurende drie jaar normaal dan is er zeer waarschijnlijk geen chronische leverontsteking en kan de patiënt uit controle worden ontslagen.

- Is bij een negatief HBeAg het ALAT wel een keer verhoogd, dan volgt alsnog verwijzing, omdat de ontstekingsactiviteit in de tijd kan fluctueren.

In tegenstelling tot de NHG-richtlijn (versie 2007) lijkt het verstandig om iedere patiënt met HCV en iedere HbSAg-postieve patiënt toch door te verwijzen. De NHG-richtlijn maakt nog onderscheid tussen HbeAg-negatieve en -positieve patiënten. Recente gegevens laten echter zien dat Hbe-Agnegatieve chronische hepatitis B wat agressiever verloopt en bovendien het beloop (ontstaan van cirrose en/of hepatocellulair carcinoom $=\mathrm{HCC}$ ) redelijk voorspeld kan worden door het bepalen van de virale lading bij deze patiënten. Ook zwangeren moeten worden doorverwezen, omdat ook bij hen de virale lading voorspelt of de moeder antivirale 
- klachten/symptomen die zouden kunnen passen bij chronische virushepatitis (algehele malaise) bij patiënt uit risicogroep

- verhoogde transaminasewaarden (1,5-5 maal de bovengrens van normaal) bij patiënt zonder klachten/symptomen

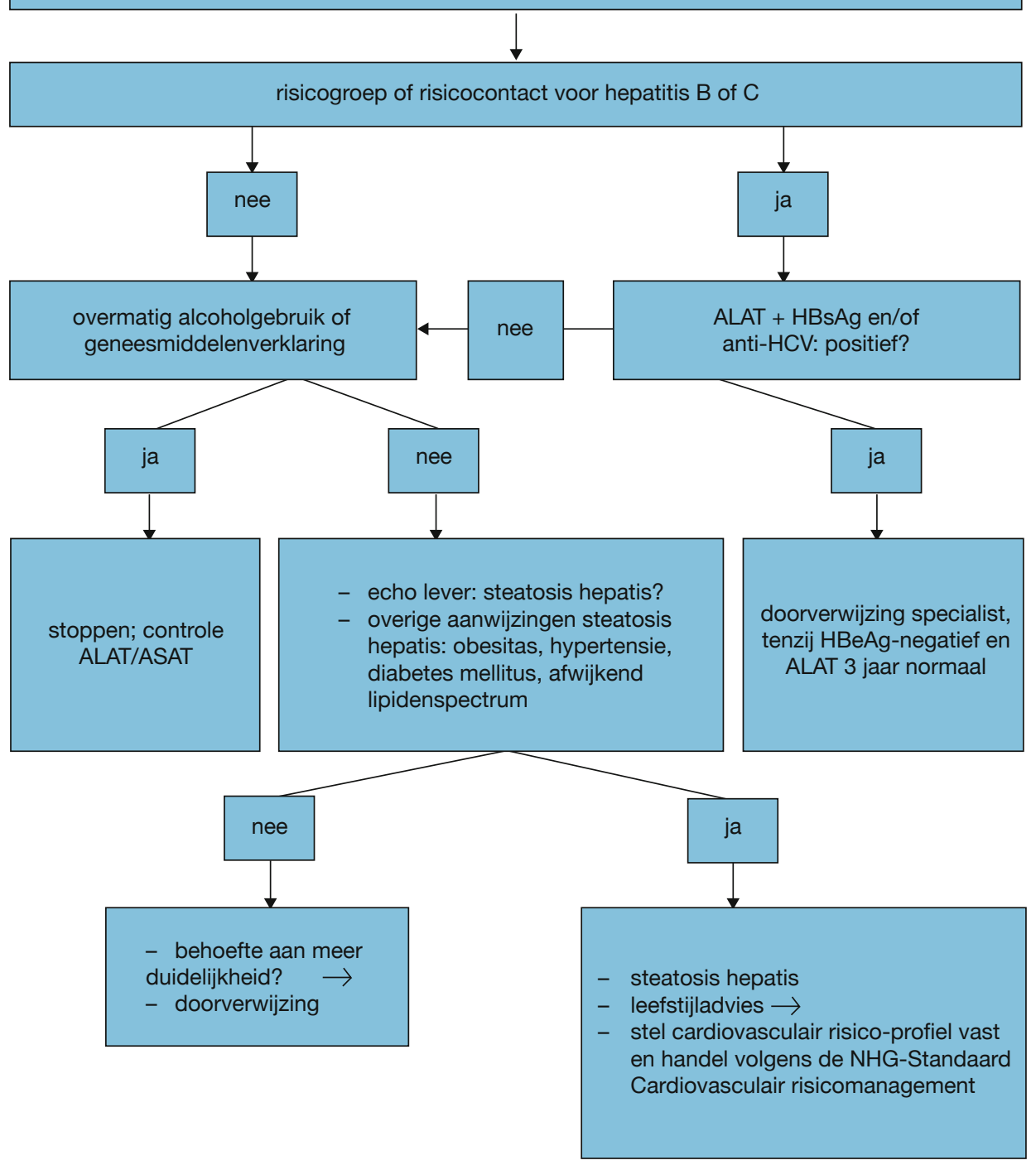

Figuur 8.1

Stroomdiagram aanvullende diagnostiek bij vermoeden van een (chronische) leveraandoening. 
behandeling behoeft, naast vaccinatie van de baby en het toedienen van antistoffen tegen HBsAg aan de pasgeborene.

Ter voorkoming van besmetting van anderen geeft de huisarts de volgende adviezen.

Patiënten met hepatitis-B Bespreek de besmettelijkheid van bloed en lichaamsvloeistoffen bij hepatitis-B en hoe overdracht naar anderen te vermijden. Ontraad patiënten met hepatitis-B onveilige seksuele contacten en motiveer ze om met hun contacten te bespreken dat deze zich laten vaccineren (zie NHG-Standaard Het SOA-consult). Geef adviezen ter voorkoming van contact met bloed van geïnfecteerden.

Patiënten met hepatitis-C Bespreek de besmettelijkheid van bloed bij hepatitis-C, en hoe overdracht naar anderen te vermijden. De kans op overdracht van hepatitis-C bij seksueel contact is klein, behalve bij homoseksuele mannen die met hiv zijn geïnfecteerd en seksuele risicocontacten hebben waarbij verwonding optreedt. Geef adviezen ter voorkoming van contact met bloed van geïnfecteerden. Adviseer de patiënt er zorg voor te dragen dat anderen contact vermijden met voorwerpen waar mogelijk zijn bloed aan zit: tandenborstels, scheerapparaat, naalden, spuiten, gereedschap voor handen voetverzorging, verbandmateriaal, maandverband en medische gebruiksartikelen. Daarnaast moet de patiënt opletten bij huidlaesies zoals wondjes, open eczeem en impetigo. Aan het gezamenlijk gebruik van tafelbestek, de badkamer, kleren en aan gewoon 'aanraakcontact' is geen risico verbonden. Bespreek de consequenties ten aanzien van een eventuele zwangerschap (verticale transmissie). Ten aanzien van werk, school en dagverblijf zijn bij normaal sociaal contact geen speciale maatregelen nodig. In specifieke situaties moet overleg plaatsvinden tussen de direct verantwoordelijken, zoals de bedrijfsarts of arbodienst en/of adviserend deskundigen. Dit geldt vooral indien de geïnfecteerde werkt in de gezondheidszorg en daar risicovolle handelingen verricht.

\footnotetext{
Personen uit de directe omgeving van een patiënt met hepatitis-C Geef adviezen gericht op het voorkomen van contact met bloed van de patiënt.

In aansluiting op de gegeven mondelinge voorlichting kan de huisarts de patiënt de NHG-patiëntenbrieven Hepatitis-A, Hepatitis-B en Hepatitis-C meegeven. Deze zijn gebaseerd op de NHGStandaard en bevatten informatie over virushepati-
}

tis en de behandeling ervan. Zie voor een overzicht van alle NHG-Patiëntenbrieven http://www.nhg. org > patiëntenvoorlichting.

\section{Therapie}

Hepatitis-B De effectiviteit van antivirale therapie bij chronisch geïnfecteerden is uitsluitend aangetoond voor $\mathrm{HbSAg}$-postieve en $\mathrm{HBeAg}$-negatieve patiënten met een hoog gehalte HBV-DNA $>2,0 \times$ $10^{4} \mathrm{IU} / \mathrm{ml}$ bij Hbe-Ag-positieve- en $>2,0 \times 10^{3} \mathrm{IU} / \mathrm{ml}$ bij HbeAg-negatieve patiënten) en verhoogde serumtransaminasewaarden. Een samenvatting van de indicaties voor de verschillende middelen bij de verschillende patiëntengroepen staat beschreven in hoofdstuk 25 Antimicrobiële therapie. Bij HBeAgpositieve patiënten is $\mathrm{HBeAg}$-seroconversie en het ondetecteerbaar worden van het virus het na te streven effect.

Het ultieme doel van de behandeling is HBsAgklaring of HBsAg-seroconversie, omdat dit leidt tot betere overlevingskansen en reductie van het optreden van HCC. Omdat dit doel echter zelden wordt bereikt, zijn er ook andere maten om de effectiviteit van behandeling aan af te meten: normalisering van de transaminasen, daling van HBV-DNA tot $<400 \mathrm{IU} / \mathrm{ml}$ en negatief worden van het HBeAg (indien aanwezig); HBeAg-seroconversie met ontwikkeling van anti-HBe en histologische afname van de ontsteking zonder verdere toename van de leverfibrose.

Tot voor kort was de eerste keuze behandeling peginterferon (bij patiënten met serotype A), omdat de kans op blijvende remissie na staken van de behandeling groter is dan bij gebruik van de (oude) virusremmers als lamivudine. Circa $35 \%$ van de HBeAg-positieven en circa $25 \%$ van de HBeAg-negatieven heeft blijvende remissie na één jaar behandeling met peginterferon. Bijwerkingen van peginterferon zijn griepverschijnselen en stemmingsveranderingen, zoals prikkelbaarheid en depressie. Daarnaast komen trombocytopenie en neutropenie veel voor. Deze behandeling is echter zwaar en steeds vaker wordt de voorkeur gegeven aan virusremmers. Deze nucleoside- en nucleotideanalogen als lamivudine, telbivudine, tenofovir en entecavir werden vroeger vooral gegeven aan patiënten die niet responderen op een behandeling met peginterferon of de behandeling niet verdragen. Deze middelen moeten langdurig (levenslang?) worden gegeven om de respons te handhaven. Resistentie treedt op bij meer dan $70 \%$ van de patiënten na vijf jaar behandeling met lamivudine, maar de nieuwere behandelingsopties geven een veel lagere kans op antivirale resistentie. $\mathrm{Na} 7$ jaar behandeling met 
entecavir heeft meer dan 90\% van de patiënten een HBV-DNA-concentratie < 400 kopieën/ml en slechts $0,8 \%$ ontwikkelt antivirale resistentie.

Bij zwangeren met chronische actieve hepatitis B, blijkend uit een zeer hoog HBV-DNA $\left(>1,0 \times 10^{9}\right.$ kopieën/ml), kan behandeling met lamivudine de kans op het falen van vaccinatie bij de pasgeborene verminderen. Dit is van belang omdat de bescherming van de pasgeborene door respectievelijk passieve immunisatie en vaccinatie niet $100 \%$ is. Behandeling wordt in dit geval gegeven vanaf week 32 tot aan de bevalling.

Hepatitis-C De belangrijkste indicatie voor behandeling is progressieve leverziekte, gekenmerkt door aanwezigheid van significante leverfibrose (ten minste porto-portale fibrose). Bij patiënten met virusgenotype 2 of 3 kan altijd behandeling overwogen worden als de patiënt dit wenst, omdat er een hoge kans is op respons en de behandeling korter ( 16 of 24 weken) is dan bij genotype 1 en 4 . De behandelingsmogelijkheden bestaan uit een combinatie van peginterferon-alfa en ribavirine (zie hoofdstuk 25 Antimicrobiële therapie). Ook hier hangt het succes van de behandeling af van de leeftijd van de patiënt, de mate van leverschade, het genotype van het virus, de snelheid van response op vier weken (RVR), de keuze/combinatie van de middelen, de bijwerkingen (therapietrouw) en eventuele co-infectie met hepatitis-B-virus of HIV. Combinatietherapie van peginterferon en ribavirine is succesvoller dan peginterferon als monotherapie; combinatietherapie is daarom nu de standaardbehandeling.

In 2012 zijn ook in Nederland de proteaseremmers telaprevir en boceprevir beschikbaar gekomen. Studies bij naïeve (niet eerder behandelde) en reeds behandelde patiënten die gefaald hebben op combinatietherapie met peg-interferon in combinatie met ribavirine, hebben laten zien dat de zgn. triple therapie (combinatie van peg-interferon, ribavirine en een proteaseremmer) het genezingspercentage meer dan verdubbelt.

Doel van de behandeling is genezing (klaring van het virus, waardoor ook de kans op cirrose en levercelcarcinoom aanzienlijk afneemt). Bij patiënten met een chronische hepatitis-C-infectie veroorzaakt door virusgenotype 1 is na 48 weken combinatietherapie met peginterferon-alfa-2b en ribavirine het virus bij 42-46\% blijvend verdwenen. Bij patiënten met virusgenotype 2 of 3 wordt klaring van het virus in bijna $80 \%$ van de gevallen al bereikt na 24 weken combinatietherapie. Ook bij kinderen zijn de behandelingsmogelijkheden in gunstige zin aan het veranderen.
Behandeling tijdens zwangerschap is wegens teratogeniteit niet mogelijk.

Behandeling van een acute hepatitis-C-infectie is in $90-100 \%$ van de gevallen effectief en daarom moeten deze patiënten onmiddellijk worden verwezen.

\subsection{Sepsis en septische shock}

Sepsis is een systemische ziekte veroorzaakt door micro-organismen (meestal bacteriën) of bacteriële toxines die in het bloed terechtgekomen zijn. Severe sepsis wordt gedefinieerd als sepsis met tekenen van orgaandisfunctie. Men spreekt van septische shock wanneer hypotensie persisteert ondanks adequate volumeresuscitatie.

Met een incidentie van circa 3 per 1.000 personen per jaar en een mortaliteit van ongeveer 40 per 100.000 personen per jaar, is sepsis een ernstig ziektebeeld. De mortaliteit loopt snel op per (extra) uitgevallen orgaansysteem (longen, nieren, lever etc.). Sepsis komt voor op alle leeftijden.

Sepsis ontstaat wanneer natuurlijke barrières in het lichaam door micro-organismen worden doorbroken. Voorbeelden zijn de huid, de mucosa van het gastro-intestinale systeem, de urinewegen of de luchtwegen. Indien deze barrières door medisch handelen al zijn beschadigd (urinekatheter, intraveneus infuus), is de kans op het ontstaan van sepsis uiteraard groter.

Vervolgens vindt een cascade van inflammatoire processen plaats, waarbij ontstekingmediërende cellen en eiwitten in het bloed vrijkomen. Dit leidt ten slotte tot de klinische symptomen van sepsis.

Een aangeboren of verworven immuundeficiëntie kan predisponeren tot het ontstaan van sepsis. Een bekend voorbeeld is sepsis op basis van gekapselde bacteriën, die snel en fulminant kan verlopen bij mensen zonder (functionele) milt.

De klinische presentatie loopt uiteen van zeer mild met nauwelijks symptomen (vooral bij jonge kinderen), tot ernstig ziek met zelfs comateuze toestanden. De symptomen zijn zeer uiteenlopend en onder andere afhankelijk van de oorsprong van de sepsis. Lokaliserende klachten kunnen een aanwijzing geven voor het focus van de sepsis. Vaak zijn deze echter afwezig. Meestal zijn er wel systemische symptomen. Ondanks een normale bloeddruk, kan er toch al ernstige hypoperfusie van vitale organen aanwezig zijn. Dit kan zich uiten in soms subtiele verschijnselen als verminderde diurese, verwardheid of een versnelde ademhaling. 


\section{Diagnose}

Men stelt de diagnose sepsis indien er een infectieus focus is met daarnaast 2 of meer SIRS-criteria. Dit zijn de zogenoemde 'Systemic Inflammatory Response Syndrome'-criteria, die uiting zijn van een gegeneraliseerde ontstekingsreactie. Deze komen dikwijls voor bij een infectie, maar kunnen ook andere oorzaken hebben. De SIRS-criteria zijn lichaamstemperatuur $<36$ of $>38^{\circ} \mathrm{C}$, ademhalingsfrequentie $>20$ per minuut, hartslag $>90$ per minuut en leukocyten in het perifere bloed $<4.000 /$ $\mathrm{ml}$ of $>12.000 / \mathrm{ml}$.

Er is geen unieke marker in het bloed om sepsis aan te tonen of uit te sluiten; wel vindt men frequent afwijkende laboratoriumwaarden die op een sepsis kunnen wijzen: leukocytose of leukopenie, stollingsstoornissen en trombopenie, hypoxemie en een verhoging van het CRP of lactaat. Afhankelijk van de anamnese en het lichamelijk onderzoek, zal men diagnostiek verrichten gericht op de mogelijke oorzaak van de sepsis (X-thorax, urinesediment, beeldvorming van de buik etc.).

Van groot belang is het om goede kweken af te nemen, alvorens antibiotische behandeling gestart wordt (zie hoofdstuk 25 Antimicrobiële therapie). Dit mag alleen achterwege worden gelaten als direct starten met antibiotica levensreddend geacht wordt en een kweekafname tijdverlies zou betekenen (zoals bij meningokokkensepsis). Bloedkweken bevestigen het klinische vermoeden, maar leveren meestal op zijn vroegst na 24 uur een verwekker op. Overigens blijven de bloedkweken in meer dan de helft van de gevallen negatief, vaak door voorafgaand antibioticagebruik. In de toekomst zal het wellicht mogelijk zijn met behulp van moleculair diagnostische technieken snel een verwekker aan te tonen. Tot die tijd zal men empirisch een antibiotische behandeling moeten starten.

\section{Therapie}

Gezien de ernst van het ziektebeeld, geldt voor alle behandelprincipes: hoe sneller, hoe beter. In het kader hiervan wordt ook wel gesproken van 'het gouden uur': als een patiënt in het eerste uur van presentatie adequaat is behandeld en daarmee (ten dele) gestabiliseerd, kan hiermee de mortaliteit aanzienlijk worden teruggedrongen. Bij hemodynamische instabiliteit of respiratoire insufficiëntie zal een patiënt op een IC-afdeling moeten worden behandeld. Hier is men beter in staat de vitale parameters frequent te controleren en direct naar bevinden te handelen.

Antibiotische therapie is de hoeksteen van de behandeling. In het algemeen wordt empirisch ge- start met intraveneuze breedspectrumantibiotica. Hierbij wordt uiteraard rekening gehouden met het meest waarschijnlijke focus van de sepsis. Zie hiervoor hoofdstuk 25 Antimicrobiële therapie.

Indien de huisarts fulminante meningokokkensepsis of postsplenectomiesepsis vermoedt, wordt aanbevolen reeds thuis met parenterale therapie (bijv. cefuroxim $750 \mathrm{mg}$ i.v. of i.m.) te beginnen en de patiënt zo snel mogelijk naar het ziekenhuis te laten transporteren. Hierover is in Nederland, waar de reisafstanden tot het ziekenhuis kort zijn, wel discussie.

Men streeft vervolgens naar een agressief volumeherstel, zeker indien de patiënt in shock verkeert. Hierbij streeft men naar een gemiddelde bloeddruk hoger dan $65 \mathrm{mmHg}$ en een diurese boven de $30 \mathrm{ml} /$ uur. De voorkeur gaat uit naar intraveneuze toediening van vocht, liefst kristalloïden $(\mathrm{NaCl}$ o,9\%) of een colloïde oplossing. Indien met voldoende vocht toedienen de bloeddruk onvoldoende op peil kan worden gehouden, zal men inotropica toedienen.

Verder is een goede saturatie van groot belang, waarbij in ieder geval wordt gestreefd naar een saturatie boven de 90\%, gemeten aan de vinger. Niet zelden zal een septische patiënt ondanks 100\% zuurstof via een mondmasker in ademhalingsproblemen komen. Dan besluit men tot intubatie en mechanische ventilatie.

In zeldzame gevallen (bij patiënten met een moeilijk controleerbare septische shock of een bacteriële meningitis) zal men intraveneus corticosteroïden toedienen. Het rationale is een relatieve bijnierschorsinsufficiëntie gedurende de acute fase van de sepsis en het voorkomen van neurologische complicaties bij bacteriële meningitis.

Voor andere ondersteunende maatregelen wordt verwezen naar hoofdstuk 20 Spoedeisende geneeskunde.

\section{Preventie}

Deze richt zich op specifieke verwekkers (o.a. vaccinatie tegen pneumokokken, groep-Cmeningokokken en Haemophilus influenzae type b).

\subsection{Toxic shock syndroom}

Toxic shock syndroom (TSS) is een ernstig, maar relatief zeldzaam ziektebeeld dat wordt veroorzaakt door toxines van Staphylococcus aureus (S-TSS) of groep-A-streptokokken (GAS-TSS). S-TSS wordt in de volksmond ook wel de 'tamponziekte' genoemd, hoewel circa de helft van de gevallen tegenwoordig niet meer gerelateerd is aan tampongebruik. S-TSS komt in ongeveer 90\% van de geval- 
len voor bij jonge, menstruerende vrouwen. GASTSS komt echter op alle leeftijden en bij beide geslachten ongeveer evenveel voor. Beide ziektebeelden treffen meestal tevoren gezonde individuen. Toch zijn er los van het tampongebruik (speciale niet meer in Nederland verkrijgbare) enkele risicogroepen aan te wijzen. Vooral een voorafgaand huiddefect (trauma, operatie, brandwond) of een banale virusinfectie predisponeren tot het ontstaan van TSS. De mortaliteit is circa $5 \%$ bij S-TSS versus meer dan $30 \%$ bij GAS-TSS.

Toxines spelen een belangrijke pathogenetische rol bij het ontstaan van TSS. Ze fungeren als superantigeen: onafhankelijk van antigeenpresenterende cellen activeren ze grote aantallen T-cellen en zetten deze aan tot cytokineproductie. Grote hoeveelheden cytokines zorgen vervolgens voor de klinische symptomen, via capillaire lekkage en directe weefselschade.

Beide ziektebeelden presenteren zich acuut. Hoge koorts en hypotensie staan op de voorgrond.

Bij GAS-TSS staat lokale, heftige pijn ter hoogte van huid of weke delen centraal. Meestal is deze pijn gelokaliseerd ter hoogte van een van de extremiteiten. Vaak zijn er ook andere lokale symptomen van ontsteking aanwezig, maar deze kunnen bij presentatie nog geheel afwezig zijn.

Bij S-TSS is er in het acute stadium vaak een diffuus exantheem. Ook de handpalmen, voetzolen en mucosae van orofarynx en vagina kunnen aangedaan zijn.

Daarnaast zijn er bij beide shocksyndromen vaak verschijnselen van aantasting van één of meerdere orgaansystemen: spierpijn, braken en diarree, conjunctivitis of faryngitis, hoofdpijn en verwardheid, of stoornissen in nier- en leverfuncties. Onbehandeld leidt TSS meestal tot multipel orgaanfalen en overlijden op korte termijn.

\section{Diagnose en differentiaaldiagnose (zie tabel 8.3)}

Men moet altijd denken aan een TSS, wanneer een tevoren gezonde persoon zich met hoge koorts en hypotensie presenteert (tabel 8.3). Differentiaaldiagnostisch kan men hierbij uiteraard ook denken aan ernstige sepsis (bijvoorbeeld door meningokokken, waarbij eveneens huidafwijkingen kunnen ontstaan), necrotiserende fasciitis (vooral wanneer lokale pijn op de voorgrond staat zoals bij GAS-TSS), syndroom van Stevens-Johnson, M. Kawasaki (bij kinderen), een ernstige zonnesteek, leptospirose of een hemorragische koorts.

Bij GAS-TSS is de bloedkweek in circa $60 \%$ positief, bij S-TSS slechts bij $5 \%$. Lokale wondkweken of kweken van vaginaal vocht kunnen de verwekker aantonen.

\begin{tabular}{|c|c|}
\hline Tabel 8.3 & $\begin{array}{l}\text { Case definitie toxic shock syn- } \\
\text { droom (volgens het Centre of } \\
\text { Disease Control). }\end{array}$ \\
\hline \multicolumn{2}{|c|}{1 koorts: temperatuur $>38,9^{\circ} \mathrm{C}$} \\
\hline \multicolumn{2}{|c|}{$\begin{array}{l}2 \text { hypotensie: systolische bloeddruk } \leq 90 \mathrm{~mm} \mathrm{Hg} \\
\text { voor volwassenen of onder } 5 \text { e percentiel voor kin- } \\
\text { deren }<16 \text { jaar óf orthostatische bloeddrukval } \geq 15 \\
\mathrm{~mm} \mathrm{Hg} \text { of orthostatische syncope / duizeligheid }\end{array}$} \\
\hline \multicolumn{2}{|c|}{3 diffuus maculair exantheem } \\
\hline \multicolumn{2}{|c|}{$\begin{array}{l}4 \text { desquamatie: begint doorgaans 1-2 weken na } \\
\text { aanvang ziekte, met name aan handpalmen en } \\
\text { voetzolen }\end{array}$} \\
\hline \multicolumn{2}{|c|}{$\begin{array}{l}5 \text { multi-orgaan betrokkenheid: } 3 \text { of meer van vol- } \\
\text { gende orgaansystemen: } \\
\text { - gastro-intestinaal: braken of diarree bij presenta- } \\
\text { tie } \\
\text { - } \text { musculair: ernstige spierpijn of stijging CK > } 2 \times \\
\text { bovenste limietnormaalwaarde } \\
\text { - } \text { slijmvliezen: vaginale, orofaryngeale en conjunc- } \\
\text { tivale hyperemie } \\
\text { - } \text { renaal: ureum of creatinine }>2 \text { bovenste limiet } \\
\text { normaalwaarde of leukocyturie } \\
\text { - hepatisch: bilirubine of transaminasen }>2 \text { bo- } \\
\text { venste limietnormaalwaarde } \\
\text { - } \text { hematologisch: trombopenie }<100.000 / \text { microl } \\
\text { - neurologisch: desoriëntatie of verandering in } \\
\text { bewustzijn zonder focale uitval in afwezigheid } \\
\text { van koorts en hypotensie }\end{array}$} \\
\hline
\end{tabular}

Therapie

Deze steunt op vier pijlers: chirurgische behandeling, antibiotica, agressieve ondersteunende therapie en intraveneuze immunoglobulines.

Bij verdenking op GAS-TSS zal direct een chirurgische exploratie van de wond moeten plaatsvinden, omdat anders necrotiserende fasciitis ontstaat en de patiënt snel overlijdt. Bij S-TSS zo snel mogelijk tampon verwijderen.

Empirisch start men met clindamycine en een bètalactamantibioticum als ceftriaxon i.v. Clindamycine onderdrukt de bacteriële toxineproductie. Bij groep-A-streptokok (GAS-)TSS vervangt men het breedspectrum bètalactamantibioticum door penicilline en bij door stafylokokken veroorzaakte TSS door flucloxacilline, zodra het antibiogram bekend is. Therapieduur in overleg, minimaal 14 dagen. 
Meestal worden patiënten op de intensive care behandeld. Vochttoediening is essentieel, vaak vele liters per dag.

Bij ernstige gevallen wordt intraveneus immunoglobulinetherapie aanbevolen. Hiermee worden de toxines onschadelijk gemaakt.

Bij invasieve GAS-infecties dienen de familieleden profylactisch antibiotica te ontvangen (zie www.rivm.nl).

\subsection{Ziekenhuisinfecties}

Een ziekenhuisinfectie is een infectie die wordt opgelopen tijdens het verblijf in een ziekenhuis, als de patiënt niet naar het ziekenhuis was gekomen, had hij de infectie niet gekregen.

Voor een deel van de infecties geldt dat deze te voorkomen zijn door het toepassen van hygiënische maatregelen, echter niet alle infecties zijn te voorkomen. Indien, door onhygiënisch handelen, een operatiepatiënt een postoperatieve wondinfectie ontwikkelt, dan is deze infectie te beschouwen als een ziekenhuisinfectie die voorkomen had kunnen worden.

Als een patiënt, die al wekenlang op de intensive care verblijft, een urosepsis ontwikkeld met een verwekker die al eerder werd gevonden in zijn katheterurine, dan voldoet deze infectie ook aan de criteria van een ziekenhuisinfectie. Het is echter bekend dat een urinekatheter binnen enkele dagen na inbrengen gekoloniseerd raakt met fecale en omgevingsflora; deze urosepsis was niet te voorkomen door het toepassen van goede hygiënische maatregelen.

De verwekkers die een rol spelen bij ziekenhuisinfecties kunnen dezelfde zijn als die ook in de thuissituatie kunnen worden aangetroffen. Daarnaast kunnen ook verwekkers aangetroffen worden die resistent zijn voor verschillende antibiotica die in het ziekenhuis vaak worden voorgeschreven. Voorbeelden van resistente ziekenhuisbacteriën zijn meticilline resistente Staphylococcus aureus (MRSA), vancomycine resistente Enterococcus faecium (VRE) en Extended Spectrum Beta-lactamase (ESBL) producerende gramnegatieve bacteriën. Bovendien kunnen ziekenhuisinfecties veroorzaakt worden door andere soorten verwekkers, die uitgeselecteerd worden in de ziekenhuisomgeving. Voorbeelden van typisch uitgeselecteerde ziekenhuisbacteriën zijn Pseudomonas aeruginosa, Acinetobacter baumannii en Stenotrophomonas maltophilia.

Sommige verwekkers beschikken over eigenschappen die ze bijzonder geschikt maakt om zich te kunnen verspreiden in een ziekenhuisomgeving. Een goed voorbeeld hiervan is Clostridium difficile.
Deze bacterie vormt sporen die resistent zijn tegen uitdroging en die niet worden gedood door de handenalcohol die normaalgesproken toegepast wordt bij patiëntencontact. Juist bij patiënten van wie de normale darmflora door antibioticagebruik onderdrukt wordt, kan Clostridium gemakkelijk uitgroeien en diarree veroorzaken.

In het algemeen geldt voor de meeste hiervoor genoemde verwekkers dat het aantonen van die verwekker niet per definitie betekent dat er sprake is van een infectie. Dragerschap of kolonisatie kan voorkomen zonder dat er sprake is van ziekte, wel zal dragerschap in de meeste gevallen aan een infectie voorafgaan.

Het bevorderen van goede huishygiëne binnen het ziekenhuis is een van de kernactiviteiten van de afdeling Ziekenhuishygiëne en infectiepreventie. Een dergelijke afdeling is binnen ieder ziekenhuis te vinden. Uitgebreide voorlichting en scholing van medewerkers over transmissieroutes wordt op structurele wijze verzorgd, zodat op de werkvloer de kennis beschikbaar is om kruisbesmettingen tussen patiënten te voorkomen.

Voor de zorg aan individuele patiënten met potentieel besmettelijke aandoeningen worden isolatieadviezen op maat gegeven. Ook worden isolatiemaatregelen geadviseerd wanneer duidelijk wordt dat een patiënt gekoloniseerd is met een bijzonder resistente verwekker, waarvan het voorkómen van verspreiding naar anderen in het ziekenhuis van belang is.

\subsection{Infecties met meticilline resistente $S$. aureus (MRSA)}

Meticilline resistente S. aureus is een Staphylococcus aureus die ongevoelig is voor de eerste keus antibiotica. Meestal is er alleen sprake van dragerschap met MRSA, maar ook infectie kan voorkomen. Alle soorten infecties die geassocieerd zijn met S. aureus kunnen ook door MRSA veroorzaakt worden.

Panton-Valentine Leukocidine (PVL) is een $S$. aureus-specifiek exotoxine dat zowel door meticilline gevoelige als resistente $S$. aureus-stammen wordt geproduceerd als de betreffende twee genen (lukF-PV en lukS-PV) aanwezig zijn. De aanwezigheid van PVL-genen in S. aureus-stammen is geassocieerd met ernstige huidinfecties en necrotiserende pneumonie.

\section{Diagnose}

De aanwezigheid van MRSA kan worden aangetoond door het kweken van uitstrijkjes van de keel, 
neus en het perineum. De neus is de voorkeursplaats voor het dragerschap, maar daarnaast kan ook een wond, een insteekplaats van een infuus of ander lichaamsvreemd materiaal zoals een beademingstube MRSA bevatten. Kweekstokken of bijvoorbeeld pus wordt op het medischmicrobiologisch laboratorium in een selectief vloeibaar medium geënt, dit om de hoogste opbrengst te behalen. De kweek kan in de regel 3 tot 5 dagen duren.

Sinds enkele jaren is ook een moleculair biologische sneltest beschikbaar. Deze test is uitstekend geschikt om in korte tijd (circa twee uur) en op betrouwbare wijze MRSA-dragerschap uit te sluiten; in dat geval kan de isolatie worden opgeheven. In sommige gevallen zal deze test MRSA-dragerschap niet kunnen uitsluiten; dan zullen de kweekresultaten afgewacht moeten worden. Het advies is om de test vooral aan te vragen bij klinische patiënten, gezien de kostenbesparing voor de kliniek door het snel opheffen van de isolatie.

\section{Preventie}

In Nederland is de prevalentie van MRSA dankzij het 'search and destroy' beleid nog steeds erg laag: $<1 \%$. Dit beleid wordt uitgevaardigd door de Werkgroep Infectie Preventie en houdt in dat patiënten die een verhoogde kans hebben op MRSAdragerschap bij opname in het ziekenhuis in isolatie worden verpleegd totdat dragerschap is uitgesloten. Ook bij polikliniekbezoek worden hygiënische maatregelen geadviseerd.

Risico op MRSA-dragerschap bestaat indien een patiënt in de afgelopen 6 maanden opgenomen is geweest of behandeld is in een buitenlandse zorginstelling of indien het een uit het buitenland geadopteerd kind betreft met een medische voorgeschiedenis.

Sinds enige tijd is bekend dat personen die beroepsmatig contact hebben met levende varkens of vleeskalveren of personen die wonen op een varkens- of vleeskalverenhouderij ook een verhoogde kans hebben op MRSA-dragerschap; daarom is ook deze groep toegevoegd aan de categorie personen met verhoogde kans op dragerschap.

Specialistische therapie

In Nederland wordt voor de behandeling van MRSA-dragerschap de SWAB-richtlijn (www.swab. nl) (Stichting werkgroep antibioticagebruik) gehanteerd. Hierbij kan behandeling worden gestart zodra de risicofactoren voor langdurig dragerschap verdwenen zijn (wonden hersteld, infuus is eruit, huidafwijkingen, bijv. eczeem, zijn tot rust geko- men). In eerste instantie wordt 5 dagen behandeld met mupirocine neuszalf en gedurende 5 dagen worden huid en haren gedoucht met chloorhexidineshampoo. Ook onderkleding en beddengoed wordt dagelijks verschoond.

Als deze behandeling niet effectief blijkt te zijn, wordt de kuur herhaald met toevoeging van twee orale antibiotica op geleide van het antibiogram, volgens het voorkeursschema van de SWAB.

\subsection{Infecties met vancomycine resistente enterokokken (VRE)}

Enterokokken zijn in principe weinig virulente bacteriën, maar bij immuungecompromitteerde patiënten kunnen enterokokken wel degelijk een klinische rol van betekenis spelen. Amoxicilline is het antibioticum van eerste keuze, maar aangezien resistentie voor dit middel in toenemende mate voorkomt, is vancomycine het 'laatste' redmiddel. Resistentie voor dit middel komt echter inmiddels ook voor. Om verspreiding binnen het ziekenhuis te voorkomen worden hygiënische maatregelen geadviseerd.

\section{Diagnose}

Dragerschap met VRE kan worden aangetoond door een rectum- of feceskweek in te sturen, die specifiek gekweekt wordt in een bouillon. Indien er sprake is van een infectie met VRE, wordt deze in het klinische materiaal aangetoond.

\section{Preventie}

In het ziekenhuis worden patiënten die gekoloniseerd zijn met VRE met isolatiemaatregelen verpleegd om verspreiding te voorkomen. Het dragerschap kan lang duren, zolang de patiënt geregeld in het ziekenhuis komt of lang opgenomen blijft, is de kans klein dat de VRE uit de darm verdwijnt. Dragerschap van maanden tot jaren is in de literatuur beschreven.

\section{Specialistische therapie}

Indien er sprake is van een infectie die behandeling noodzakelijk maakt, is op geleide van het antibiogram, in overleg met de arts-microbioloog of internist-infectioloog behandeling vaak mogelijk. 

gramnegatieve staven (MR-GNS)

In een ziekenhuisomgeving komt kolonisatie of infectie met gramnegatieve bacteriën geregeld voor. Als er sprake is van resistentie voor meerdere eerstekeuze antibiotica uit verschillende klassen, worden hygiënische maatregelen geadviseerd om verspreiding binnen het ziekenhuis te voorkomen.

\section{Diagnose}

Voor het aantonen van deze verwekkers volstaat de reguliere bacteriologische diagnostiek. Voor het opsporen van dragerschap met MR-GNS kan het afnemen van een rectumwat geadviseerd worden.

\section{Preventie}

Afhankelijk van de verwekker en het type resistentie kunnen hygiënische maatregelen geadviseerd worden, zoals het dragen van schort en handschoenen bij direct contact met de patiënt.

\section{Specialistische therapie}

Op geleide van het antibiogram kan passende antibiotische therapie geadviseerd worden bij een infectie. Een effectieve dragerschapbehandeling is nooit beschreven.
Clostridium difficile is een sporenvormende anaerobe grampositieve staafvormige bacterie die normaal voorkomt in de darm. Indien het toxine-positief isolaat betreft, kan door toxineproductie diarree ontstaan. Het gebruik van bepaalde antibiotica, zoals ciprofloxacine of cefalosporine, is geassocieerd met het ontstaan van Clostridium-diarree, doordat de darmflora grotendeels onderdrukt wordt.

\section{Diagnose}

Het aantonen van toxine is mogelijk in de feces, ook een bacteriologische kweek is mogelijk.

\section{Preventie}

Goede handenhygiëne is van essentieel belang. Hierbij moet vermeld worden dat de handen met water en zeep gewassen moeten worden, omdat de sporen niet door handenalcohol gedood worden. Het schoonmaken van de patiëntenkamer dient met chloor te gebeuren.

\section{Specialistische therapie}

Therapie met metronidazol is de eerste keuze, in hardnekkige gevallen kan vancomycine uitkomst bieden.

Over het algemeen zijn deze pathogenen (behoudens C. difficile) onschuldig in de thuissituatie. 